\title{
送配水システムのライフサイクルアセスメント における社会的割引率に関する一考察
}

\author{
長谷川 高平 1 . 荒井 康裕 2 ・ 小泉 明 2 \\ 1学生会員 首都大学東京大学院 都市環境科学研究科（†192-0397 東京都八王子市南大沢 1-1） \\ E-mail : hasegawa-kouhei@ed.tmu.ac.jp \\ 2正会員 首都大学東京大学院 都市環境科学研究科（192-0397 東京都八王子市南大沢 1-1）
}

\begin{abstract}
近年，送配水システムの資産管理をより合理化するためにライフサイクルアセスメント（LCA）の概念を 応用したシステム最適化が行われる事例が増えてきたが, その結果を大きく左右する社会的割引率（SDR） の在り方についてこれまで十分な議論がなされてこなかった，そこで本研究は，SDR 見直しの方向性を確 立するとともに今後の関連研究が解決すべき課題を明らかにすることを目的に既往研究の現在価值化の適 用事例及び理論の整理と送水システムを対象としたLCAへのSDR の感度分析を行った。事例整理と感度 分析を通して，（1）実勢の利回り及び対象国債の償還年限と現行の SDR の乘離，（2）温室効果ガス排出へ の減価償却の適用は不適切である，（3）相対的に高い SDR の維持による将来世代との不公平の拡大，の 3 点を指摘した。 また，今後の SDRの見直しの方向性として対象とする国債の償還年限の長期化とともに 40 年以上の SDR には聥減型 SDR の概念を適用することを提案した。
\end{abstract}

Key Words: life cycle assessment, life cycle cost, carbon footprint, water distribution system, declining population, social discount rate

\section{1. はじめに}

近年，日本の水道事業体の多くが人口減少と節水 意識の向上による水需要減少に伴う問題に直面して いる。 これに伴い, 給水収益の減少という経営面で の問題は勿論, 施設効率の低下や管内流速の低下に よる残留塩素濃度の低下という新たな課題が浮き彫 りになっている。一方, 橋梁やトンネルのようなイ ンフラ施設と同様に施設の老朽化という問題にも直 面している。つまり，人口減少による給水収益の減 少の一方で老朽化する施設への再投資が求められる 厳しい状態にあるということになる.

これらの新たな問題に対処するため, 多くの事業 体ではアセットマネジメント (AM) として施設の老 朽化や年度予算を考慮した上で合理的な投資計画を 策定し，その計画の中で水需要の減少に合わせた施 設のダウンサイジングを推進することで管路更新費 用やポンプ運転費用の削減を図っている ${ }^{1), 2)}$. 中で も，水道資産額全体の約 7 割 $^{3)}$ を占めるとされる管 路の AM 及びダウンサイジングの理論を確立するこ とは事業体の持続性に大きく関わる非常に重要な分 野であると言える。初期投資（管路布設費）に相当
する管路口径を大きくとれば, 管路摩擦損失が減少 することでポンプ運転費も小さくなるが，逆に初期 投資を削減するために管路口径を小さくとれば管路 摩擦損失が上昇し, ポンプ運転費が大きくなる。 そ のため, 一概に人口減少に合わせて縮径することが 全体の費用を最小化するとは限らない特徵を持って いる.こうした観点の下, 水道施設のライフサイク ルアセスメント $(\mathrm{LCA})^{4)} に よ り$, 施設更新をより合 理的に行なうことを目的とした研究が行われるよう になってきている.これらの研究により, 既存の $\mathrm{AM}$ の捉え方である管路の布設年度を中心とした更 新時期の設定や単純なダウンサイジングとは異なる 考え方でライフサイクルコスト（LCC）やライフサ イクル $\mathrm{CO}_{2}\left(\mathrm{LCCO}_{2}\right)$ を最小化する提案がされるな ど，知見の蓄積が進んできた。

一方, LCAに抒いては製品や施設の製造から廃棄 までの長期間に渡る事業評価が必要になる。そのた め, LCCにおいては社会的割引率 (SDR) を適用し, 将来発生する費用を現在価值（PV）及びその総和 （NPV）に変換し事業評価を行なうことが求められ る。しかし，日本で行われている送配水システムの LCA の多くがこの SDR を考慮していない，更に， 
SDR の設定根拠となっている実勢の 10 年物国債に そぐわない設定が続いている問題がある.

そこで本研究では，SDR 見直しの方向性を確立す るとともにSDR が与える影響について今後の関連 研究が解決すべき課題を明らかにすることを目的と し, 送配水システムの LCA への現在価值化の適用に 関して適用事例と理論に限定してこれまでの知見と 課題を整理するとともに著者らの既往研究5)にSDR の感度分析を実施する。

\section{2. 送配水システムにおける LCA のレビュー}

\section{（1）海外の知見}

筆者らの知る限り，送配水システムの LCA では Filion $5^{6)}$ が初めての実施事例にあたる。この研究 では，管路の寿命を $10,20,50,100$ 年と設定し，管 路の事故率やリサイクルなどを考慮した LCA を実 施している. LCAの結果, 50 年程度の頻度で管路を 更新することが LCC の観点から望ましいことなど が明らかになっている。

2008 年には, $\mathrm{Wu} ら^{7)}$ が送配水システムにおける 管路更新計画に扔いて管路口径を決定変数とし, $\mathrm{LCC}$ と $\mathrm{LCCO}_{2}$ を最小化する多目的最適化を通して $\mathrm{LCC}$ と $\mathrm{LCCO}_{2}$ のトレードオフ関係の存在を確認し た。 それ以降, 関連研究が多く発表されるように なった. $\mathrm{Wu} ら^{8)}$ は炭素税を用いて $\mathrm{LCCO}_{2}$ を $\mathrm{LCC} に$ 変換することで得られる総 LCC を最小化する単目 的解とそれを行わない多目的最適化で得られた解を 比較している。この研究では, 単目的と多目的最適 化の優劣について, 多目的最適化ではパレート最適 解の集合からなる Pareto Optimal Front が意思決定に 有効なシステム投資水準と GHG 削減効果のトレー ドオフ関係を提供できることなどから多目的最適化 のほうが送配水システムの最適化には好ましいと結 論づけた。また, 2008 年からこれまで継続的に SDR が送配水システムの最適化に与える影響について分 析が行われている (3.（1）で説明). 2013 年からは これまでの対象システムの管路を一斉に更新すると いう前提を見直し，各管路の更新時期も考慮した LCA が研究されはじめた. Prosser ら ${ }^{9)}$ はLCC の最 小化を目的に実在するシステムの管路更新順序の最 適化を行っている。この論文では管路の供用年数を 優先して更新する場合と LCC を優先して更新する 場合での比較を行っている. Roshani and Filion ら ${ }^{10)}$ は管路事故による被害額や漏水による影響を考慮し た管路更新時期最適化モデルをネットワーク状の配 水管網に適用し, 予算制約の有無が最適更新時期に
与える影響を分析している。 2014 年にはそれまでの 知見を活用し, 送配水システムの LCA が可能なソフ トウェア ${ }^{11)}$ が開発，発表されてきた。また，Stokes

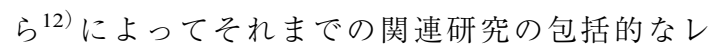
ビューがなされ, 本論の主題である SDR や炭素税と いった外部経済的要素がLCAに与える影響の分析 がより行われるべきだとの指摘がなされている.

\section{（2）日本の知見}

日本では, 厚生労働省が管路やポンプなどを網羅 した積算に係る費用関数 ${ }^{13)}$ を公表し, 水道技術研究 センターが $\mathrm{CO}_{2}$ 算定の原単位 ${ }^{14)}$ を整備したことを受 け, 2012 年からこれらを活用した送水システムの LCA が行われ始めた。堀川ら ${ }^{15)}$ はポンプ圧送に依 存する送水システムを対象にLCAを実施し，管路施 設の $\mathrm{LCCO}_{2}$ の内 $99.6 \%$ が建設過程で発生し, ポン プの $\mathrm{LCCO}_{2}$ の内, $99.5 \%$ が運転過程で発生する結果 を得ている。 また，ポンプ圧送に与える影響が大き い管路の口径を維持したケースではそれらを縮径し たケースよりも $\mathrm{LCCO}_{2}$ が小さくて済むという結果を 受け，費用だけではなく $\mathrm{LCCO}_{2}$ 削減の観点からもポ ンプ運転を考慮したシステム更新が求められると主 張している。荒井ら ${ }^{16)}$ は高低差などが異なる 5 種の 送水システムに打ける LCA を実施し, 大口径管が $\mathrm{LCCO}_{2}$ を大き削減する点やダウンサイジングだけ ではなく，自然流下のシステムを今後より一層考え るべきだと主張している。荒井ら ${ }^{17)}$ は人口減少下で の送水システムの LCA において流速や呼び径が異 なる 5 つの口径候補における $\mathrm{LCC}$ 及び $\mathrm{LCCO}_{2}$ を算 定し, 過度なダウンサイジングは人口減少下であっ ても $\mathrm{LCC}$ 及び $\mathrm{LCCO}_{2}$ の観点からは望ましくはなく, 運転過程を考慮した緩やかなダウンサイジングが有 効であることを示した。しかし，この結論は 100 年 という評価期間において管路：40 年毎, ポンプ: 20 年毎に更新するケースのみで得られた結論であっ た。 そこで, 同様のシステムを対象に管路とポンプ のライフサイクルを共に $20,40,80$ 年と増やした上 でそれぞれを組み合わせた計 9 ケースでの LCA が 行われている ${ }^{18)}$ ，検討の結果，管路は長い間隔で更 新することで $\mathrm{LCC}$ 及び $\mathrm{LCCO}_{2}$ の多くを占める建設 ステップの頻度を減らすことが $\mathrm{LCC}, \mathrm{LCCO}_{2}$ 双方の 最小化に貢献することが明らかなった。一方, ポン プは水需要量の減少に合わせてこまめに更新するこ とで $\mathrm{LCC}$ 及び $\mathrm{LCCO}_{2}$ 双方の殆どを占める運転過程 の負担を減らすアプローチが有効であることが明ら かとなった。しかしながら,これらの研究は, LCC 及び $\mathrm{LCCO}_{2}$ に対して現在価值化を適用せず，時間軸 によって異なる価值判断を総合評価に導入出来てい 
表-1 対象文献で使われた SDR

\begin{tabular}{|c|c|c|}
\hline 著者 & 年度 & 社会的割引率 \\
\hline \multirow[t]{4}{*}{ Wu et al. 7$), 22), 23), 8)$} & 08 & $0 \%, 8 \%$, Gamma \\
\hline & 08 & $0 \%, 1.4 \%, 8 \%$ \\
\hline & 09 & $0 \%, 1.4 \%, 2 \%, 4 \%, 6 \%, 8 \%$, HMT \\
\hline & 10 & $0 \%, 8 \%$ \\
\hline 森 万年) & 10 & $0 \%, 2 \%, 4 \%, 8 \%$ \\
\hline MacLeod and Filion ${ }^{25)}$ & 12 & $0 \%, 1.4 \%, 3 \%, 8 \%$ \\
\hline Roshani et al. ${ }^{26)}$ & 12 & $0 \%, 1.4 \%, 8 \%$ \\
\hline Roshani and Filion ${ }^{27)}$ & 14 & $0 \%, 1.4 \%, 8 \%$ \\
\hline
\end{tabular}

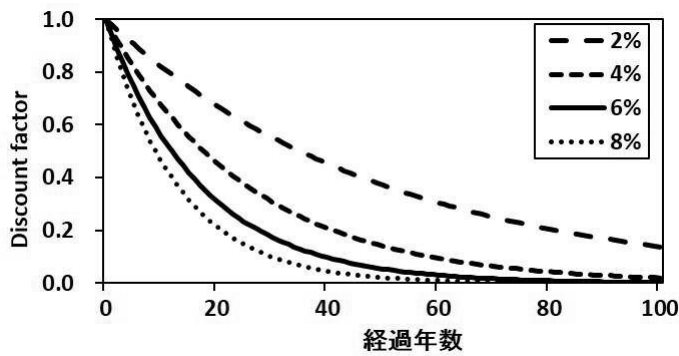

図-1 各 SDR におけるDF の推移

ないという重要な問題を抱えている。

\section{3. 現在価値化の適用事例}

（1）送配水システムの LCA に SDR が与える影響

これまで海外を中心にSDR が LCA を考慮した送 配水システムの最適化に与える影響が分析されてき た。それらで用いられた SDR を表-1にまとめる。 また，SDR を用いた各年度 $t$ の現在価值 $\left(P V_{t}\right)$ の算 定式は式（1）のとおりである。なお，この時に $C_{t}$ を 1 とした時に得られる各年度の換算係数を Discount Factor（DF）という，DF の計算結果を図-1に示す.

$$
P V_{t}=\frac{C_{t}}{(1+S D R)^{t}}
$$

ただし, $P V_{t}$ : 現在価值, $C_{\mathrm{t}}$ : 費用, $t$ : 年度.

送配水システムの LCA を考慮した最適化におけ るSDR の影響についての議論が 2008 年から活発に 行われてきた。まず, Simpson ${ }^{19)}$ がそれまでの SDR に関する議論をまとめ, 送配水システムへの影響を 考察するとともに様々な主張があることを考慮して 感度分析を実施すべきであると主張した。その後, 2010 年までに Wu らによって多くの論文が発表され た. $\mathrm{Wu} ら^{7)}$ は初めて聥減型20)を含む SDR を送配水 システムの LCA を通した多目的最適化に適用し, 高 いSDR が運転過程で発生する費用や GHG 排出を大 きく削減する結果, 最適な口径が小口径側にシフト する傾向を明らかにしている。また，同年に「Stern Review $^{21)} 」$ で用いられた $1.4 \%$ というSDR を初めて
適用している 22 ）２０09 年には，多種の SDR を送配 水システムの LCA を考慮した配水池の設置計画に 適用し, SDRの違いが多目的最適化で得られる解集 合に与える影響を明らかにしている23)。また，英国 の Her Majesty's Treasury（HMT） ${ }^{24)}$ の提唱する聥減 型 SDR の適用もこの時初めて行われた.

2012 年からは送配水システムの LCA を通してカ ナダの気候変動政策にSDR が与える影響について カナダの実在するシステムを対象にケースス夕 ディーが行われている. MacLeod and Filion ${ }^{25)}$ はそれ までの炭素税や SDR に関する議論をまとめ, カナダ の気候変動政策として用いられる可能性がある炭素 税とSDR の将来シナリオを作成し，それらを対象の 送配水システムに適用した。その結果，高い炭素税 と低いSDRの組み合わせが同国の気候変動政策を 強く後押しするとの結論を得た. Roshani ら ${ }^{26)}$ は才 ンタリオ州のシステムに扔いて，作成したシナリオ を用いて送配水システムの単目的最適化を遺伝的ア ルゴリズムによって行った，検証の結果，作成した シナリオでは $\mathrm{LCCO}_{2}$ が政府の目標に達しないとの結 論を得ている. Roshani and Filion ら ${ }^{27)}$ はオンタリオ 州のシステムに拈ける AM でのケーススタディーを 実施し，炭素税が与える影響が限定的である点や高 い炭素税や低いSDR が運転費や漏水による損失, 漏 水に伴う修理によって発生する維持管理費の削減を 促進する早期の更新や修繥を促進する効果があるこ とが明らかとなっている。

一方，日本では 2.（2）でレビューした送配水シス テムの LCAにおいて，SDR を適用した形跡は見ら れず, 十分な検討がなされていない点が指摘できる. 唯一, 類似のものとして森ら ${ }^{28)}$ の研究が挙げられる. この研究では, 超長期に渡る水道管路更新計画の事 業評価に SDR の感度分析を実施している。しかし, あくまで経済面からの評価に着目したものであり, GHG 排出に対する SDR の適用には言及していな い.したがって, 送配水システムの LCA や事業評価 におけるSDR に関する知見が十分に蓄積されてい るとは言い難く, SDR の捉え方や実際の影響につい ての認識が十分になされていないと考えられる.

\section{(2) GHG 排出への SDR 適用}

現在価值化はそもそも将来の金銭に対して適用す るものであって, 排出量取引制度を想定しない中で は GHGに対して安易に適用できるものではない. これまでの関連研究の適用事例をまとめ, どのよう な理由で GHG に対しての SDR の適用を正当化出来 るのかを理論的に整理しなくてはならない.ここで は，その前段として既往の送配水 LCAに打ける 
(a) 10 年物

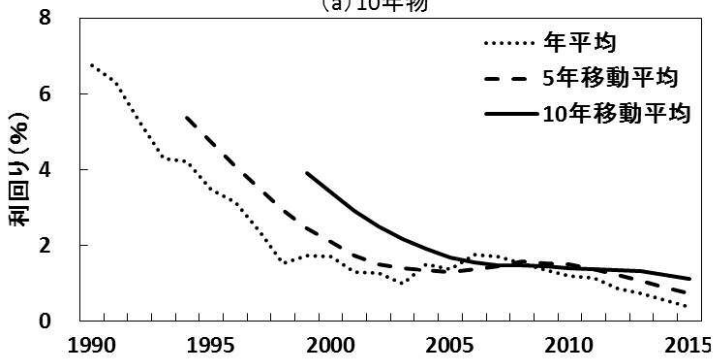

(b) 40 年物

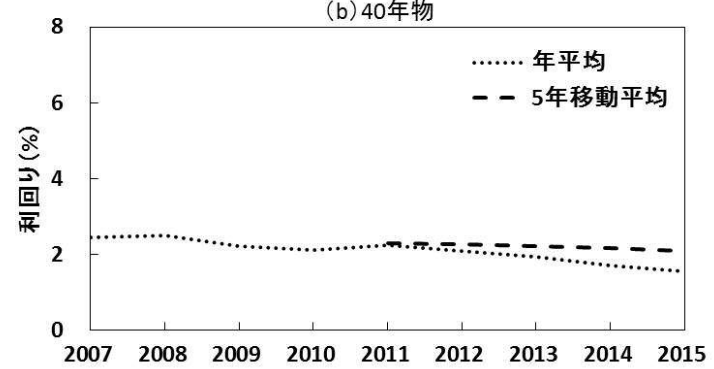

図-2 近年の利回りの推移

GHG に対する SDR の適用事例などをまとめる.

$\mathrm{Wu}$ ら $^{23)}$ は GHGにも同じ SDR を適用すべきとす る主張29)とそれぞれ異なる SDR を使用すべきとい う主張 ${ }^{30)}$ があることを提示した。 また，その中で IPCC が GHG 排出の影響を算定する際に $0 \%$ の SDR を用いている事実 ${ }^{30)}$ と将来の技術革新を考えるとプ ラスの SDR GHG 排出に用いるべきだとの主張 ${ }^{31)}$ から GHG 排出の SDR が $0 \%$ のケースと費用の SDR と等率として扱う 2 つのケースを採用している。結 果として, GHGにも割引を行ったケースでは将来の GHG 排出 (運転過程) の影響も低く評価されるため, 建設時の $\mathrm{GHG}$ 排出が少なく，運転時の $\mathrm{GHG}$ 排出の 大きい高所への配水池建設が有利になるという結果 が得られている。

炭素税のアプローチで言えば, 先述の $\mathrm{Wu} ら^{8)}$ は 炭素税による単目的最適化において, 費用には割引 を行なう一方で GHG 排出には割引を行わない手法 を採用している。一方で MacLeod and Filion ${ }^{25)}$ は上 記の議論を踏まえた上で GHG 排出に費用と同率で の割引を行い, その後に炭素税を用いて貨幣化を 行った後, 費用の単目的としての送配水システムの 最適化を行っている。 その理由として, Roshani and Filion $^{26)}$ は GHG 排出に対しての SDRの適用に関し て様々な議論があることを踏まえた上で, カナダの GHG 排出に課される費用は電力料金の上乗せとし て同一の費用として徴収される予定のため, 費用と GHG 別々にSDR を用いることは不適切だとしてい る. $\mathrm{Du} ら^{32)}$ は早期に排出された $\mathrm{GHG}$ は後に排出さ れたものよりも長い滞留を持って環境に悪影響を与 えるとして，正のSDRを採用している。

また, GHGの計上方法として減価償却を適用する ものもある. Du ら ${ }^{32)}$ は減価償却を適用し, 管路建 設に係る GHG 排出が長期間に渡って減価償却され るために管路更新間隔が長い場合には運転費低減を 重視した大口径管の採用が望ましいという結果が得 られている。 また, 水道技術研究センターが出版し た手引き14)でも GHGに対して減価償却を適用した
LCA が行われている.

これらより，SDRと GHGに関する適用事例に関 する議論は以下のように整理することが出来る.

a) GHG 自体への SDR 適用の是非は早期に排出さ れた GHGの滞留から肯定的な意見がある。一 方，適用を否定する意見は見つからなかった。

b) GHG 排出に適用する SDR は将来の不確実性や 技術革新，滞留による影響の観点から正の SDR を用いる見解が一般的である。

c） GHG 排出に適用する SDR は IPCC ${ }^{33)}$ が用いた $0 \%$ を適用するケースと費用の SDR と同率の SDR GHG 排出にも採用するケースがある。

d）管路建設費などの資本形成由来の GHG 排出に 対して減価償却を適用するアプローチがある.

\section{4. 社会的割引率の理論と課題}

\section{（1）長期利回りを用いた SDR の問題}

日本の公共事業における費用便益分析に主に用い られる SDR は4\%である。これは，国土交通省のマ ニュアル ${ }^{34)}$ が推奨していることがその理由である. また，水道の費用便益分析に関するマニュアル ${ }^{35)} も$ 国土交通省のマニュアルに準拠し，同率の SDR を設 定している. その根拠として 10 年物の国債利回り が挙げられている。これを用いる理由として, 長期 に渡る政府の資金調達コストを反映している点が挙 げられる。また，倫理という主観からその率自体が 容易に左右すること自体に問題があるためとの指摘 もあり ${ }^{36)}$ ，利回りという客観的指標が必要という観 点もある. 加えて, 国土交通省が 2009 年に発行した マニュアル ${ }^{34)}$ において，1986 年から 2002 年までの 利回りの様々な移動平均值を示し, $4 \%$ の SDR の妥 当性を示した。しかし，それ以後はSDR が見直され たという事実は筆者らの知る限りはない。近年の国 債の利回りの推移 ${ }^{37)}$ を示した図-2(a)を見てみると, 2000 年以降は 4\%を切り, 2015 年にはおよそ $1 \%$ あ 
(a)年別GHG排出
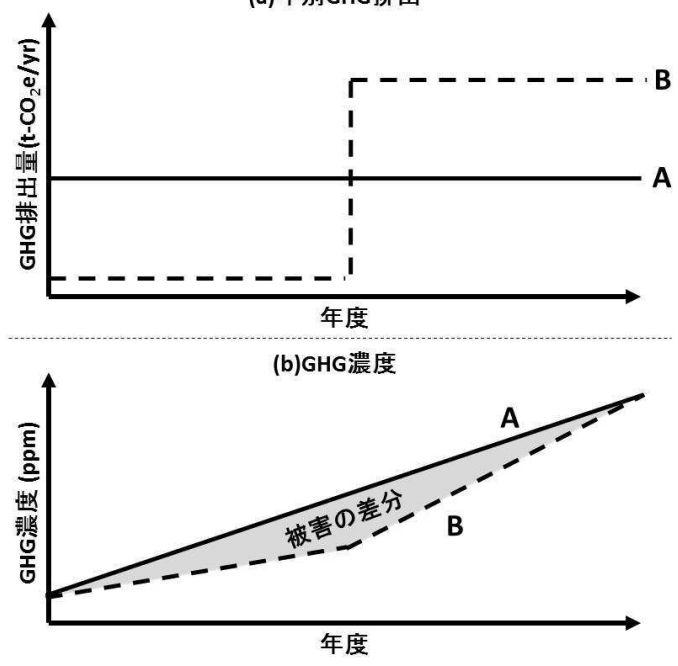

図-3 GHG 排出と社会的被害の関係

るいはそれ以下となっている。そして，2016年 2 月 にマイナス金利に達した現状を考えると，この低下 傾向は続くと考えるのが妥当である。

一方で管路の供用年数が 40 年を超えていること や水道の事業評価マニュアル ${ }^{35)}$ が算定期間を 50 年 と定めているにも関わらず，10 年物の国債利回りを 用いることがそもそも適切ではないという指摘が出 来る。一般的に償還年限が長くなるほどに様々なリ スクに晒される可能性が高いためより長期な国債の 利回りは高くなる。しかし, 現行で最長の償還年限 を持つ 40 年物の国債利回り (2007 年発行開始)の推 移を示した図-2 (b) を見てみると, $2 \%$ 前後で利回り が推移していることが分かる.

研究分野では, 阪田・林山ら ${ }^{36), 38)}$ は 4\% の SDR の設定に批判的な視点を持った上で死亡率を考慮し た効用関数で SDR の算定結果を 2002 年に発表して いる，死亡リスクを考慮した場合にもそうでない場 合に比べて SDR は高くはなるものの, 1992 年頃ま で4\%を上回らないことを示した，加えて，SDRは 全体的に低下する傾向にあるが，やや上昇する傾向 も期間の評価期間終盤には見られ，一年毎の変動も あることなどから定期的にSDRの見直しを行なう ことが必要であると主張している。また，より近年 では高齢化が進行する社会で固定的な SDR を用い ると将来の勤労世代の負担を過小評価し, 最適な水 準以下での投資を促進すると指摘されている ${ }^{39)}$.

よって, 実勢の利回りと現状用いられている SDR の乘離, ならびに既往研究の指摘を考えると, 公共 事業の意思決定を大きく左右する SDR について, 2009 年以降行われていない見直しを本格的に行なう
時期に来ていると筆者は考えている

\section{（2） GHG への現在価値化の適用合理性}

3.（2）で整理されたように, GHGに対する SDR の適用は GHGの大気中への滞留があるために合理 的であるとされ，早期の排出の方がより大きい影響 を与えるためにプラスの SDR を適用することが合 理的だとされてきた。ここでは, GHG 排出への現在 価值化の適用に関する理論を整理する.

$\mathrm{CO}_{2}$ をはじめとする $\mathrm{GHG}$ の多くは排出後数年か ら数千年以上の単位で大気中に滞留し続ける. IPCC の報告 ${ }^{40)}$ によると, $\mathrm{GHG}$ 排出の $75 \%$ 以上を占める $\mathrm{CO}_{2}$ の大気寿命はこれまでの送配水システムの LCA の最長期間である 100 年後において，およそ $30 \%$ か ら $55 \%$ が滞留し, 1000 年後にも $15 \%$ から $40 \%$ が滞 留し続けるとされている。また, Azar and Sterner $ら^{41)}$ によると, 人為的排出による大気中の $\mathrm{GHG}$ 濃 度と GHG 濃度に応じた被害は直線的比例関係があ ると指摘されている。これらに従うのであれば, 図 -3に示す関係が成り立つことになる。図-3(a)のよ うに期間内の排出量が同じで排出経路が異なる $\mathrm{A}$ と B の 2 つの案を考える. A 案は B 案に比べて前半期 の排出量が多く, 後半期の排出量は B 案の方が多い とする。この際に対象のシステムが寄与した大気中 の GHG 濃度上昇分は図-3（b）のように表現ができ る.したがって, 前半期の排出量が多い A 案は評価 期間全体に渡って GHG 濃度が B 案に比べて高い状 態が続くことになる。先述のとおり, GHG 濃度とそ れに応じた被害は直線的比例関係があるので双方の 案の $\mathrm{GHG}$ 濃度の差分が気候変動による被害の差分 となる。このことより，ある単位量の GHG 排出が 社会全体に与える被害量は早期であるほどに高いと 考えられ，排出された時期によって異なる価值を持 つというという判断に繋がっている。 そのため, Azar and Sterner ら ${ }^{41)}$ の指摘するように GHG 排出の 時間的価值の差異を表現し, 早期の排出に対しての 重み付けを高くする正のSDR 用いたケースが見 られる理由である。これが 3. (2) の（a）と（b）の 見解の基礎となっていると整理できる.

\section{（3）GHG に適用するSDR の設定に関する理論}

3.（2）の（c）で整理したようにこれまでの送配水 システムの LCA では, GHG に対して $0 \%$ の SDR を 用いる，あるいは費用に適用する SDR と同率の SDR を用いるかのアプローチが取られてきた。 しか し，4.（2）で説明したように GHG に対する現在価 值化の適用は金銭的価值の評価に関する議論とは別 の理由で正当化されており，市場の利回りをこれま 
表-2 HMT の聥減型割引率

\begin{tabular}{ll}
\hline 期間 & SDR \\
\hline $1-30$ 年 & $3.5 \%$ \\
\hline $31-75$ 年 & $3.0 \%$ \\
\hline $76-125$ 年 & $2.5 \%$ \\
\hline $126-200$ 年 & $2.0 \%$ \\
\hline $200-300$ 年 & $1.5 \%$ \\
\hline 301 年以上 & $1.0 \%$ \\
\hline
\end{tabular}

表-3 管路口径の候補と設定条件

\begin{tabular}{l}
\hline 口径候補 \\
\hline 条件 \\
口径: 極小 管内流速 $3.5 \mathrm{~m} / \mathrm{s}$ 上回らない \\
\hline 口径: 小 $\quad$ 管内流速 $2.5 \mathrm{~m} / \mathrm{s}$ 上回らない \\
\hline 口径: 中 $\quad$ 管内流速 $1.5 \mathrm{~m} / \mathrm{s}$ を回らない \\
\hline 口径: 大 「口径: 中」よりも1ランクアップ \\
\hline 口径: 極大「ロ径: 中」よりも2ランクアップ
\end{tabular}

での費用に対する SDR として設定する理論をその まま GHG の SDR の設定の理論とするのは適切では ないとする指摘がある ${ }^{41), 42)}$ 。また, GHG が数百年, 数千年以上の時間軸で滞留するため, 評価期間のあ る時点で排出された $\mathrm{GHG}$ による被害は超長期に渡 り，市場で観察される利回り自体そういった超長期 の選好を含んではいない. GHG 排出の影響が持つ 時間軸が費用の時間軸よりも長いにも関わらず，費 用に適用するSDR と同率の SDR を用いることは図 -1にあるように GHG 排出によって受ける超長期の 被害をほぼ無視することを意味する。この観点を無 視して相対的に高いSDRを用いた場合，現在の世代 が経済活動という利益を得る代わりに後の世代が温 暖化問題という被害に晒されるというバイアスが強
くなるという問題がある。 そのため, GHG 排出の評 価に関しては将来世代との公平性確保の観点から費 用に適用する SDR よりも GHG 排出へ適用する SDR を低くとるべきだと指摘がなされている ${ }^{42)}$.

このように倫理面から SDR を捉える考え方は「規 範的アプローチ」と呼ばれ, 逆に実際の市場で観察 される利子率や眝蓄率から $\mathrm{SDR}$ を求める考え方を 「記述的アプローチ」と呼び, 過去に Stern が 2006 年 に発表した「Stern Review ${ }^{21)} 」 て ゙$ 用いられた低率な 1.4\%のSDRを巡って記述的アプローチをとる Nordhaus $^{43)}$ をはじめとする研究者 ${ }^{44)-46)}$ から規範的 アプローチをとるSternに対する批判的な意見が あった。この議論はSDRの感度分析を含む Stern Reviewに関する補足資料 ${ }^{47)}$ の公表とその感度分析 が不適切とする批判 ${ }^{48)}$ が 2010 年になされたように 規範的アプローチと記述的アプローチを巡る議論が 続いており，長期的な経済評価に用いるべき SDRの 議論に決着はついていない.

3. (2)の（c）でまとめられたように, IPCC ${ }^{30)}$ で用 いられた $0 \%$ を $\mathrm{GHG}$ の現在価值化に用いる手法は 規範的アプローチに基づいたものと言え，費用に適 用する SDR と同率の SDR を用いるというのは記述 的アプローチに基づいたものであったと言える。こ れらの適用手法が適切だったかどうかは双方のアプ ローチの議論の決着如何に依存し，事業評価や送配 水システムの LCA においては双方のアプローチに 基づいた分析が必要だ考えられる。

\section{（4）派減型割引率}

3.（1）でまとめたように，送配水システムの LCA に扮ける SDR の感度分析事例では HMT や Gamma と呼ばれる派減型割引率が使用されている。聥減型 割引率 (Declining Discount Rate：DDR）とは, HMT が 発行する Green Book ${ }^{24)}$ にて指定され，公共事業評価

表-4 LCC 及び LCCO2 の NPV の計算結果

(a)LCC[百万円]

\begin{tabular}{|c|c|c|c|c|c|}
\hline \multicolumn{2}{|c|}{ 更新間隔 } & \multicolumn{4}{|c|}{ 社会的割引率 } \\
\hline 管路 & ポンプ & $0 \%$ & $2 \%$ & $4 \%$ & $8 \%$ \\
\hline \multirow{3}{*}{20} & 20 & 中: 30,673 & 中: 16,866 & 中: 11,792 & 中: 8,278 \\
\hline & 40 & 中: 30,771 & 中: 16,904 & 中: 11,809 & 中: 8,289 \\
\hline & 80 & 中: 37,701 & 中: 17,196 & 中: 11,932 & 中: 8,353 \\
\hline \multirow{3}{*}{40} & 20 & 中: 22,603 & 中: 12,769 & 中: 9,406 & 中: 7,266 \\
\hline & 40 & 大: 23,208 & 中: 12,991 & 中: 9,509 & 中: 7,318 \\
\hline & 80 & 大: 23,961 & 中: 13,284 & 中: 9,632 & 中: 7,382 \\
\hline \multirow{3}{*}{80} & 20 & 大: 17,945 & 中: 10,772 & 中: 8,493 & 中: 7,402 \\
\hline & 40 & 大: 18,077 & 中: 10,939 & 中: 8,575 & 中: 7,083 \\
\hline & 80 & 大: 19,276 & 大: 11,455 & 中: 8,839 & 中: 7,207 \\
\hline
\end{tabular}

(b) $\mathrm{LCCO}_{2}\left[\right.$ ton- $\left.-\mathrm{CO}_{2}\right]$

\begin{tabular}{|c|c|c|c|c|c|}
\hline \multicolumn{2}{|c|}{ 更新間隔 } & \multicolumn{4}{|c|}{ 社会的割引率 } \\
\hline 管路 & ポンプ & $0 \%$ & $2 \%$ & $4 \%$ & $8 \%$ \\
\hline \multirow{3}{*}{20} & 20 & 極大: 163,418 & 極大: 86,453 & 極大:58,027 & 極大: 38,059 \\
\hline & 40 & 極大: 172,169 & 極大: 90,387 & 極大: 60,345 & 極大: 39,015 \\
\hline & 80 & 極大: 188,549 & 極大: 96,060 & 極大: 62,788 & 極大: 40,053 \\
\hline \multirow{3}{*}{40} & 20 & 極大: 143,646 & 極大: 76,603 & 極大: 52,530 & 極大: 35,651 \\
\hline & 40 & 極大: 154,117 & 極大: 81,158 & 極大: 54,963 & 極大: 36,743 \\
\hline & 80 & 極大: 170,497 & 極大: 86,831 & 極大: 57,046 & 極大: 37,781 \\
\hline \multirow{3}{*}{80} & 20 & 極大: 131,115 & 極大: 71,221 & 極大: 50,072 & 極大: 35,002 \\
\hline & 40 & 極大: 140,750 & 極大: 75,534 & 極大: 52,411 & 極大: 36,049 \\
\hline & 80 & 極大: 161,265 & 極大: 82,642 & 極大: 55,473 & 極大: 37,349 \\
\hline
\end{tabular}



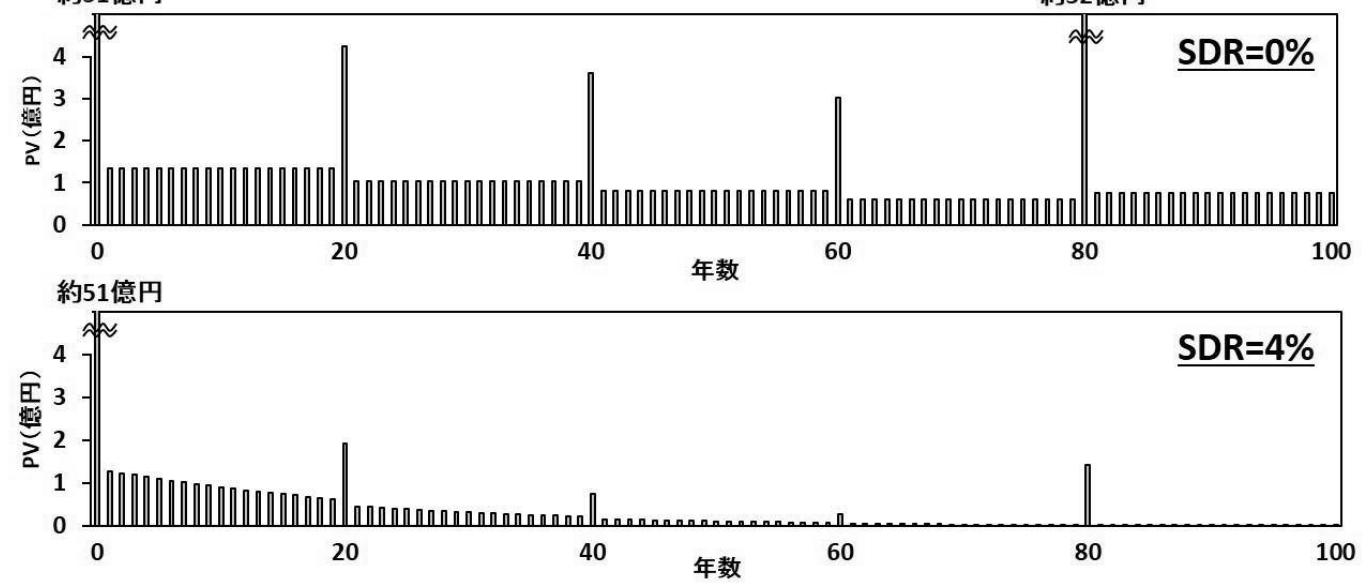

図-4 SDR が $0 \%$ 及び $4 \%$ の時の年度別の現在価值（管路： 80 年毎，ポンプ：20 年毎更新）

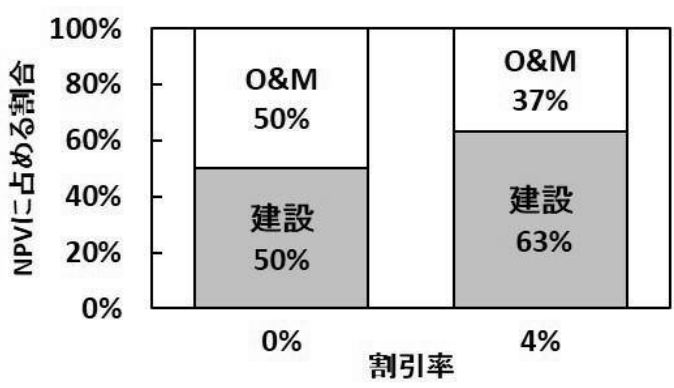

図-5ＬCCにおける建設と運転維持管理の比率

に対して公式に採用されているものや Weitzman の 提唱する Gamma discounting ${ }^{20)} に$ に代表されるもので あり，表-2のように時間が経過するほどに率が低下 する形をとるSDRである，日本では，大谷ら ${ }^{49)}$ が主 要先進国や国際機関に打ける公共事業に用いられて いるSDR についてその調査と理論についての包括 的なレビューを行っており，その中で割引率が時間 とともに逓減する DDR の適用事例をまとめている.

時間派隇の理由として, Weitzman ${ }^{20)} や$ Gollier and Weitzman $^{50)}$ による将来の SDR に関する不確実性の 導入による SDR 時間莪減の証明や不確実性の増加 に伴う個人の時間選好率の低下という実証実験結果 の反映 ${ }^{51)}$ がある，英国では，SDRの算定に式 (2)の ラムゼイルールを採用しているが，時間経過ととも に時間選好率が低くなるということは SDR が時間 の経過とともに低くなっていくということになる.

$$
S D R=\rho+\theta g
$$

ただし， $\rho$ :時間選好率， $\theta$ : 限界効用の弾力性, $g$ : 消費の成長率.
DDRの適用は未だに決着のつかない規範的アプ ローチと記述的アプローチの議論の双方を考慮して いるという点でも有効である．4.（3）で説明したよ うに規範的アプローチは遠い将来の世代が受ける被 害や便益を軽視してはならないという観点から相対 的に低いSDRを設定しょうとするものであるのに 対し, 記述的アプローチは市場利子率や貯蓄率を考 慮して相対的に高いSDR を設定しようとするもの であった，規範的アプローチを支持し，利回りより も相対的に低いSDR を採用すると短期的な収益が 十分に得られない可能性がある一方, 記述的アプ ローチを支持し，相対的に高いSDR を採用すると将 来世代への負担が大きくなってしまうという問題を 抱えることとなる。しかし，DDR を適用することに より，現存する国債利回りを可能な限りSDRに反映 し，短期的な収益の理論的整合性を確保すると共に 利回りを直接反映できない長期に扔けるSDR を聥 減させ，将来の価値を過度に低く見積もらないとい う取扱が可能になる。

\section{5. 送水システムにおける SDR の感度分析}

\section{（1）条件設定}

ここでは，著者らが以前実施した送水システムへ の $\mathrm{LCA}^{5)}$ に欠けていた NPV の算定を行い，その結果 を提示する。また，その結果より SDR が送配水シス テムの LCA に与える影響と実務上の意思決定に与 える影響について考察する。なお，LCAを行なうに あたっての水理条件や費用関数などの諸条件は既往 研究 ${ }^{5}$ と同様とする。本分析で用いる管路口径の候 補と設定条件は表-3のと拈りである。感度分析で用 
割引前

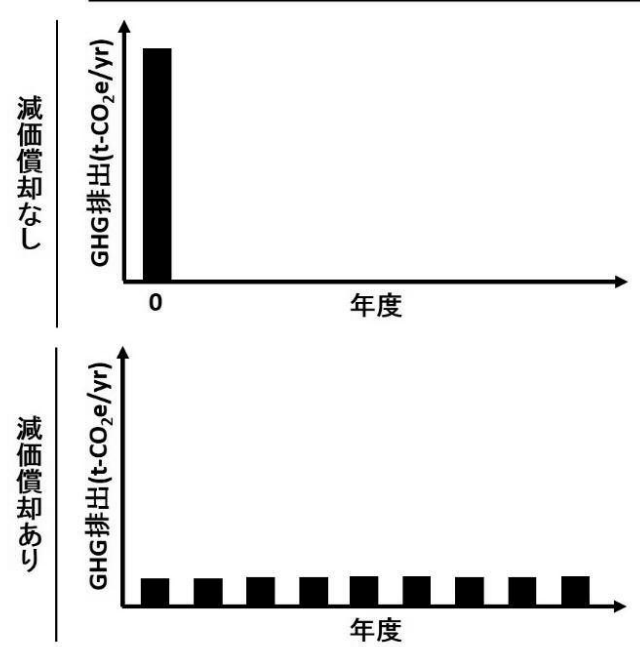

割引後
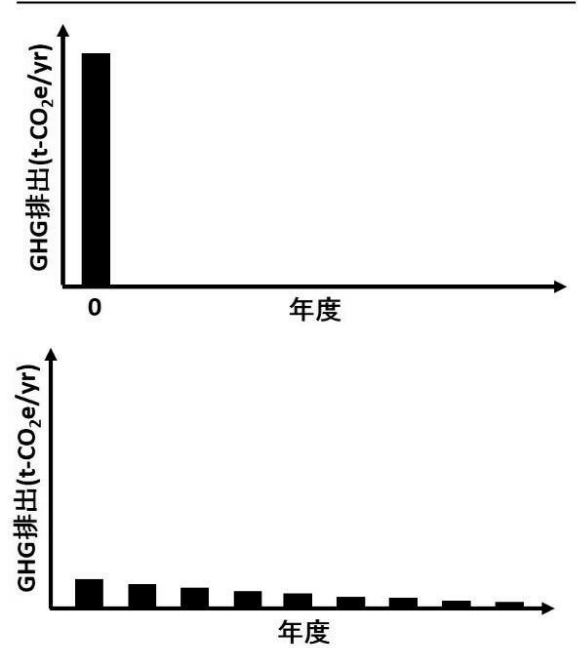

図-6 現在価值化に減価償却が与える影響の例

いるSDRは，既往研究の結果である $0 \%$ に加え，図 -2 に示した現行の国債利回りを反映した $2 \%$, 日本 で最も一般的である現行の $4 \%$ ，表-1にあるように 既往研究で用いられた最大值である $8 \%$ の計 4 つと し, 各年度の PV は式（1）によって算出した。また, 評価年度は評価開始点を 0 年目とし, 評価終了時を 100 年目として取り扱った。

（2）SDRによる最適口径縮小のメカニズム

感度分析の結果を見ると，表-4にあるように「口 径: 大」から「口径：中」へ最適口径が縮小したケー スがいくつかある。 その中で管路: 80 年毎, ポンプ: 20 年毎に更新するケースを例に SDR 適用による最 適口径縮小のメカニズムを分析する.

図-4 は SDR $=0 \%$ と $4 \%$ に打ける年度別費用の PV とその合計值である NPV を示している. SDR $=0 \%$ のケースと比較して 4\%のケースでは割引によって 特に 40 年以降に発生する費用に価值が殆ど発生し ていないことが分かる。この割引によって毎年発生 する O\&M 費と単発の建設費の関係に変化が生じ る.人口減少下に拈いては将来の水需要が減少して いくのに伴い口径が縮径され, ポンプ出力も落ちて いく，そのため，評価開始時の投資（管路建設費及 びポンプ整備費）が全体に占める割合が高い。加え て, 評価開始時の初期投資は割引されない一方, 将 来発生する O\&M 費は図-1にあるように年々指数関 数的に小さくなる $\mathrm{DF}$ を乗じることで減少していく. この結果として, 建設投資が占める割合がより強調
され, NPV に占める建設費の割合が高くなる(図-5). 上記の NPV に占める建設費の割合の上昇が最適口 径にも影響を与える。 O\&M 費が大きく割り引かれ, 建設費が NPV に占める割合が上昇するということ は LCC の最小化においては $\mathrm{SDR}=0 \%$ の時以上に建 設費, 特にその殆どを占める管路建設費の削減が必

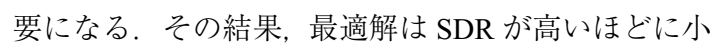
口径側にシフトすることになる。

$\mathrm{LCCO}_{2}$ に関してはSDRによる影響はなかった。 したがって，今回の分析では 4. (3) で言及した規範 的及び記述的アプローチどちらを採用しても $\mathrm{LCCO}_{2}$ には大きな影響はないと言える。しかし，3.（1）で まとめた既往研究では $\mathrm{LCCO}_{2}$ を指標にした際にも費 用と同様のメカニズムで最適口径が縮小することが 報告されている．今回の検討では口径を変数とした 一般的な管路ネットワーク最適化とは異なり, 管路 毎の更新時期や口径候補などの変数の数を絞った形 での検討を行っているためにSDRに対する感度が 低かったと考えられ，変数に多様性を持たせた最適 化では $\mathrm{LCCO}_{2}$ を指標とした場合でも SDR が高いと 最適口径が縮小寸る傾向が得られると考えられる.

\section{6. 考察}

ここでは文献レビューと感度分析の結果を踏ま え, 今後の水道事業に用いる SDR の見直しの方向性 と将来の管路システムの AM に現行の SDR などが 
与えるバイアスについて考察を加える.

\section{（1）水道事業における SDR 見直しの方向性}

今後の SDR 見直しにおいて，筆者はSDR を実勢 の利回りに合わせて引き下げると同時に設定対象と する国債の償還年限をより長期，水道事業の費用便 益算定マニュアル ${ }^{35)}$ の指定する 50 年の評価期間に 従うのであれば，現状として最長の償還年限である 40 年を対象の償還年限とする方向性を推奨したい. 実際，オランダやドイツのような主要先進国が実勢 の利回りの低下を理由にSDR の下方修正を行って いる事例もある上，日本よりも SDR が低い主要先進 国も複数存在する ${ }^{49)}$.

一方, 対象とする国債の償還年限を 40 年まで引き 伸ばしても費用便益算定マニュアルの指定する 50 年とは年数の一致が十分に取れていないという問題 と LCA のようなより長期な事業評価の場合に用い る SDR としては理論的に整合性が取れていないと いう問題が残る。この問題の解決策として DDRの 適用が挙げられる. Green Bookでは 1 年目から 30 年目までは $3.5 \%$ の SDR を採用しているが, これは 英国の発行する国債の最長償還年限が 30 年である ためであり，この期間までは将来の利回りが予想可 能であるとの前提で 30 年までは実勢の国債利回り を反映したSDR を設定している，日本にこれを当 てはめると, 国債の最長償還年限である 40 年目まで は 40 年物国債の金利を反映した SDR を設定し, そ れ以降は聥減する形で次第に SDR が低下するよう にすることが適切であると言える。また，DDRの適 用は 4.（4）で言及したように環境面に対する割引率 を巡る規範的アプローチと記述的アプローチ双方の 主張を満たす点でも有効であると言える。

\section{（2）減価償却の適用不合理性}

本来, 減価償却というのは固定資産として生産を 行なう設備に対して老朽化による資産価值減衰を表 現することと次回更新時に向けた資金積立を目的と して金銭価值に適用されるものであり, GHG 排出へ

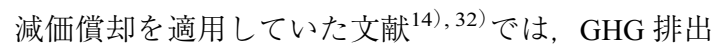
に減価償却を適用することに対する理論的な説明が 十分になされていない。ここからは，上記の $\mathrm{GHG}$ に対する正のSDR を用いた現在価值化の理論が正 しいとの立場に立った上で GHG 排出に減価償却を 適用することが誤った意思決定をもたらす可能性が あることを指摘する.

この問題は以前から Cherubini and Stromman ${ }^{52)}$ や O’ Hare ら ${ }^{53}$ 指摘しているように $\mathrm{GHG}$ への減価償却 の適用によって本来の $\mathrm{GHG}$ 由来の被害を不適切に
低く見積もることであると説明できる，例として， 評価開始時を 0 年目とし， 0 年目に管路建設がある と考える（図-6)。減価償却がない場合，管路建設に 由来する $\mathrm{GHG}$ 排出を発生年度に全て計上している 一方, 減価償却ありの場合は減価償却期間に従って 0 年目に発生した $\mathrm{GHG}$ 排出を多年度に分割して計 上している。これらに割引を適用すると, 減価償却 なしのケースでは $D F_{0}$ が 1.0 なので割引適用前後の 価値変化は生じない。減価償却ありの場合は図-1に あるように $D F_{1}$ 以降が 1.0 よりも次第に小さくなる ために減価償却なしのケースに比べて GHG の NPV が小さくなってしまう。白結果として, 本来評価 されるべき価值よりも早期の GHG 排出の重要性を 低く見積もるようになってしまう.

冒頭で述べたように管路建設費を決める管路口径 とポンプの運転費は管路摩擦損失を原因とした卜 レードオフ関係にあり，管路口径の設定によって後 に発生するポンプ運転費が変化する. GHG に対し て減価償却を適用した場合, より早期に排出される 管路の建設由来の $\mathrm{GHG}$ の方が後に発生するポンプ 運転費よりも重要にも関わらず，管路建設由来の GHG がポンプ運転費と同様に計上され，同等に割り 引かれていく，その結果, 本来は管路口径を小さく することでより早期に排出される管路建設由来の GHG 排出を抑えることが重要にも関わらず, 減価償 却の適用によって大口径の管路が好ましいとする矛 盾した解を導出することとなる。したがって, GHG 排出による環境への影響を適切に評価するという面 からすると管路建設に由来する GHG 排出への減価 償却の適用は避けられるべきだと考えられる。

\section{（3）将来世代との投資の公平性}

送配水システムの $\mathrm{AM} に$ に扔いては, 投資の平準化 が一つの重要な要素となる。人口減少下の日本にお いて, 将来の世代に老朽化した施設の更新投資を集 中させることは予算や職員及び業者の数，また，意 思決定に参加できない世代への負担の押し付けとい う倫理的な観点からして望ましくないからである。

5.（2）で説明したように，高いSDR を適用すると 管路口径に依存する管路建設費の削減が好ましくな り，ポンプ運転費が高くなるシステムを構築するこ ととなる。これは, 高いSDRによるイニシャルコス トの重視とポンプ運転費や漏水, 管路事故に伴う被 害など日常的に発生する O\&M 費の軽視と言い換え ることが可能であり, 将来世代への負担増が高い SDRによってもたらされる可能性が示唆される.

管路の更新順序を考えた際，SDR が高くなると， $\mathrm{DF}$ が小さくなるので, 莫大な費用が必要になる管路 
の更新投資を後延ばししたほうがNPV としては優 れたものとなる。したがって，時代背景を反映しな い過度に高いSDRの採用は世代間の不公平を生む 原因となり得る。これまでは, 人口増加と水道普及 率の向上による接続世帯数の増加による給水収益上 昇が見込まれた。 そのため, 将来世代の負担を考え るよりも現在の負担を軽減することのほうが妥当で あったと考えられる。一方で, 人口減少時代に突入 し, 将来の給水収益の減少と更新投資の増加が見込 まれる状況下ではこの意味が逆になり，早期の投資 によって将来世代の負担を軽減することが有効であ ると考えられる。つまり, 将来の価值を高く評価す る低いSDRの適用が将来世代との投資の公平性と いう倫理的な観点からは妥当だと考えられる.

ただし，2.（1）で指摘したように更新の先延ばし による O\&M 費の増大や漏水の発生といった要素を 考慮した時にいつ管路を更新したほうが良いかとい う時間軸を考慮した最適化も含めたLCAにおいて, SDR の感度分析を実施した例は筆者らの知る限りは 存在せず，その影響について定量的に実証されてい ない。また，管路やポンプの資本費に減価償却を適 用した際にSDRの影響をどのように受けるかにつ いての検討もなされていない.この点も関連研究が 今後行なうべき要素であると指摘できる.

\section{7. おわりに}

本研究では, 送配水システムに扔けるLCA と現在 価值化の適用に関する既往研究のレビューを行い, そこで用いられた SDRに関する理論を整理した後, 実際の LCA 事例にSDR の感度分析を実施した。 そ して, 文献レビューや感度分析結果から水道事業に おけるSDR 見直しの方向性と SDR が実務的な意思 決定に与える影響を考察した。本研究で明らかにし た傾向や将来への示唆は送配水システムだけではな く, 建設, O\&Mのライフサイクルを持つ多くのイン フラ関連政策や研究にも当てはまると考えられる。

SDR の設定を巡る議論は本論でまとめたように統 一した見解があるわけではなく，ある一定の客観的 見解の中でこれまでSDR が決められてきた。 それ に相当するのが各省庁のマニュアル ${ }^{34), 35) て ゙ あ り, ~}$ 現在使用されている長期国債の利回りとなる。長年 改訂が行われていないSDRについても現行の $4 \%$ と 国債利回りの乘離は勿論のこと, 環境面, 投資水準 の公平性などの観点からも SDR を低くする方向で の再検討が人口減少時代に突入し，これまでの「右 肩上がり」を前提とする理論とは異なるパラダイム
シフトの中で必要であると考えられる.

今後の課題として，6.（3）で挙げた SDR が管路の 最適投資時期に与える影響の分析や管路やポンプの 資本に対する減価償却適用による影響の比較, それ らの検討を可能とするモデルの構築が必要だと言え る。また, 今回は炭素税や炭素の社会的費用といっ た $\mathrm{GHG}$ の費用換算について触れていない，加えて， SDR と不確実性の関係性についても触れていない. 今後は上記の課題に関する議論の整理や最適化問題 への適用にも取り組んでいきたい.

謝辞：本論文の一部は, 公益財団法人 水道技術研究 センターによる Rainbows プロジェクトの研究成果 であることを付記し, 本成果が水道インフラの更新・ 維持管理の一助となるならば幸甚である.

\section{参考文献}

1）小椋和生, 三山健一郎, 尾瀬良治, 津田厳:水需要減少等 を踏まえた送水ポンプ整備の検討, 平成 27 年度全国 会議（水道研究発表会）講演集, 2015, pp. 524-525.

2）肥田悠, 小出大輔:配水管網整備事業の事業量及びダウ ンサイジングによるコスト縮隇効果に関する考察, 平 成 27 年度全国会議（水道研究発表会）講演集, 2015, pp. $376-377$.

3) 日本水道協会: 水道の安全保障に関する検討会報告書, 2010.

4) 井村秀文:建設の LCA, オーム社, 2001.

5) 荒井康裕, 長谷川高平, 阿部翔, 小泉明, 稲員とよの: 送 水ネットワークを対象としたライフサイクルコスト 及び $\mathrm{CO}_{2}$ 排出量 - 管路及びポンプのライフサイクル に着目した分析一, 土木学会論文集 G, Vol. 71, No. 6, pp. II-377-II-386, 2015.

6) Y. R. Filion, H. L. MacLean, B. W. Karney:Life-Cycle Energy Analysis of a Water Distribution System, J. of Infrastructure Systems, Vol. 10, No. 3, pp. 120-130, 2004.

7) W. Wu, A. R. Simpson, H. R. Maier: Multi-objective Genetic Algorithm Optimisation of Water Distribution Systems Accounting for Sustainability, Proc. Water Down Under 2008, pp. 1750-1761, 2008.

8) W. Wu, H. R. Maier, A. R. Simpson: Single-Objective versus Multiobjective Optimization of Water Distribution Systems Accounting for Greenhouse Gas Emissions by Carbon Pricing, J. Water Resour. Plan. Manag., Vol. 136, No. 5, pp. 555-565, 2010.

9) M. E. E. Prosser, V. L. Speight, Y. R. Filion:Life-cycle energy analysis of performance- versus age-based pipe replacement schedules, J. AWWA, Vol. 105, No. 12, pp. E721-E732, 2013. 
10) E. Roshani, Y. R. Filion:Event-based approach to optimize the timing of water main rehabilitation with asset management strategies, J. Water Resour. Plan. Manag., Vol. 140, No. 6, p. 4014004, 2013.

11) C. S. Stokes, A. R. Simpson, H. R. Maier:A computational software tool for the minimization of costs and greenhouse gas emissions associated with water distribution systems, Environ. Model. Softw., Vol. 69, pp. 452-467, 2015.

12) C. Stokes, A. Simpson, H. Maier:The cost-greenhouse gas emission nexus for water distribution systems including the consideration of energy generating infrastructure: an integrated conceptual optimization framework and review of literature, Earth Perspect., Vol. 1, No. 1, pp. 1-17, 2014.

13）厚生労働省健康局水道課:水道事業の再構築に関する 施設更新費用算定の手引き, 2011.

14）公益財団法人水道技術研究センター:管路施設の LCA に関する研究, 持続可能な水道サービスのための管路 技術に関する研究(e-Pipe プロジェクト), 2011, pp. 5-1-5-108.

15）堀川博哉, 荒井康裕, 小泉明, B. Bakri:水道管路ネット ワークの環境影響評価に関する一考察, 土木学会第 67 回年次学術講演会, pp. 171-172, 2012.

16）荒井康裕, 小泉明, 堀川博哉, 稲員とよの, B. Bakri:水道 管路システムのライフサイクル $\mathrm{CO}_{2}$ に関するモデル 分析, 土木学会論文集 G (環境), Vol. 69, No. 7, p. III 337-III_344, 2013.

17）荒井康裕, 小泉明, 堀川博哉, 恩田雄太郎, B. Bakri:水道 管路インフラの LCA 的評価に関する研究一送水ネッ トワークを対象としたライフサイクルコスト及び $\mathrm{CO}_{2}$ 排出量の把握一, 土木学会論文集 $\mathrm{G}$ (環境), Vol. 69, No. 6, pp. II_351-II_358, 2013.

18）長谷川高平, 荒井康裕, 小泉明, 稲員とよの:送水ネット ワークにおける管路・ポンプの更新間隔を考慮したラ イフライクルコスト及び $\mathrm{CO}_{2}$ の把握, 平成 27 年度全 国会議（水道研究発表会）講演集, 2015, pp. 372-373.

19) A. R. Simpson:Selecting a discount rate for evaluating water distribution projects-The sustainability controversy, in Water Distribution System Analysis; August 17, 2008, Vol. 20, pp. 1-12.

20) Weitzman, Martin:Gamma Discounting, Am. Econ. Rev., Vol. 91, No. 1, pp. 260-271, 2001.

21) N. H. Stern, Her Majesty's Treasury: Stern Review: The economics of climate change, 2006.

22) W. Wu, A. R. Simpson, H. R. Maier: Water distribution system optimisation accounting for a range of future possible carbon prices, in Proceedings of the 10th Annual Water Distribution Systems Analysis Conference, WDSA 2008, 2008, pp. 278-289.
23) W. Wu, A. R. Simpson, H. R. Maier: Accounting for greenhouse gas emissions in multiobjective genetic algorithm optimization of water distribution systems, J. Water Resour. Plan. Manag., Vol. 136, No. 2, pp. 146-155, 2009.

24) Her Majesty's Treasury: The Green Book: appraisal and evaluation in central government: Treasury guidance, Stationery Office, 2003.

25) S. P. MacLeod, Y. R. Filion: Issues and Implications of Carbon-Abatement Discounting and Pricing for Drinking Water System Design in Canada, Water Resour. Manag. , Vol. 26, No. 1, pp. 43-61, 2012.

26) E. Roshani, S. P. MacLeod, Y. R. Filion: Evaluating the Impact of Climate Change Mitigation Strategies on the Optimal Design and Expansion of the Amherstview, Ontario, Water Network: Canadian Case Study, J. Water Resour. Plan. Manag., Vol. 138, No. 2, pp. 100-110, 2012.

27) E. Roshani, Y. Filion: Water Distribution System Rehabilitation under Climate Change Mitigation Scenarios in Canada, J. Water Resour. Plan. Manag., Vol. 141, No. 4, p. 4014066, 2014.

28）森正幸, 稲員とよの, 小泉明, 渡辺晴彦, 沼田篤男:水道 管路の超長期的な更新投資の経済性評価に関する研 究, 水道協会雜誌, Vol. 79, No. 7, pp. 2-12, 2010.

29) G. C. Van Kooten, A. Grainger, E. Ley, G. Marland, B. Solberg:Conceptual issues related to carbon sequestration: Uncertainty and time, Crit. Rev. Environ. Sci. Technol., Vol. 27, No. S1, pp. 65-82, 1997.

30) P. M. Fearnside: Time preference in global warming calculations: a proposal for a unified index, Ecol. Econ. , Vol. 41, No. 1, pp. 21-31, 2002.

31) P. M. Fearnside, D. A. Lashof, P. Moura-Costa:Accounting for time in mitigating global warming through land-use change and forestry, Mitigation and Adaptation Strategies for Global Change, Vol. 5, No. 3, pp. 239-270, 2000.

32) F. Du, G. J. Woods, D. Kang, K. E. Lansey, R. G. Arnold: Life Cycle Analysis for Water and Wastewater Pipe Materials, J. Environ. Eng., Vol. 139, No. 5, pp. 703-711, 2013.

33) P. M. Fearnside: Time preference in global warming calculations: A proposal for a unified index, Ecol. Econ., Vol. 41, No. 1, pp. 21-31, 2002.

34）国土交通省:公共事業評価の費用便益分析に関する技 術指針（共通編）, 2009.

35）厚生労働省健康局水道課:水道事業の費用対効果分析 マニュアル, 2011.

36）阪田和哉, 林山泰久:社会資本整備における社会的割引 率に関する研究, 土木計画学研究・講演集, Vol. 26, 
2002.

37）財務省:過去の国債の入札情報, 2015. [URL]. Available: http://www.mof.go.jp/jgbs/auction/past_auction_schedule/. [アクセス日: 2016 年 2 月] .

38）阪田和哉, 林山泰久:会資本ストックの社会的割引率に 関する実証的研究, 応用地域学研究, No. 7, pp. 99-109, 2002.

39) S. Segi, K. Kobayashi: Planning Implication of Inveriant Population Assumptions in Depopulation and Aging Sociery, J. Japan Soc. Civ. Eng. Ser. D3 (Infrastructure Plan. Manag., Vol. 69, No. 5, pp. I_205-I_216, 2013.

40) P. Ciais, C. Sabine, G. Bala, L. Bopp, V. Brovkin, J. Canadell, A. Chhabra, R. DeFries, J. Galloway, M. Heimann: Carbon and other biogeochemical cycles, in Climate Change 2013: The Physical Science Basis. Contribution of Working Group I to the Fifth Assessment Report of the Intergovernmental Panel on Climate Change, Cambridge University Press, 2014, pp. 465-570.

41) C. Azar, T. Sterner: Discounting and distributional considerations in the context of global warming, Ecol. Econ., Vol. 19, No. 2, pp. 169-184, 1996.

42）大瀧正子:地球温暖化問題の経済分析における将来世 代の厚生評価の問題点-技術代替性と割引率をめぐる Nordhaus, Cline, Stern の比較を事例にして, 立命館国際 研究, Vol. 21, No. 2, pp. 281-299, 2008.

43) W. D. Nordhaus: A review of the "Stern review on the economics of climate change”, J. Econ. Lit. , Vol. 45, No. 3, pp. 686-702, 2007.

44） R. M. Carter, C. R. De Freitas, I. M. Goklany, D. Holland, R. S. Lindzen, I. Byatt, I. Castles, D. Henderson, N. Lawson, R.
McKitrick:The Stern review: a dual critique, World Econ. , Vol. 7, No. 4, pp. 165-232, 2006.

45) J. P. Weyant:A critique of the Stern Review's mitigation cost analyses and integrated assessment, Rev. Environ. Econ. Policy, Vol. 2, No. 1, pp. 77-93, 2008.

46) P. Dasgupta: The Stern Review's economics of climate change, Natl. Inst. Econ. Rev., No. 199, pp. 4-7, 2007.

47) N. Stern:Technical Annex to Postscript, 2007.

48) A. Saltelli, B. D’Hombres:Sensitivity analysis didn't help. A practitioner's critique of the Stern review, Glob. Environ. Chang., Vol. 20, No. 2, pp. 298-302, May 2010.

49) 大谷悟, 佐渡周子, 今野水已, 土谷和之, 牧浩太郎:主要 先進国等の公共事業評価に適用される社会的割引率, 土木学会論文集 D3 (土木計画学), Vol. 69, No. 5, pp. I_ 163-I_171, 2013.

50) C. Gollier, M. L. Weitzman:How should the distant future be discounted when discount rates are uncertain?, Econ. Lett. , Vol. 107, No. 3, pp. 350-353, 2010.

51) OXERA:Social Time Preference Rate for Use in Long-term Discounting., OXERA Press, 2002.

52) F. Cherubini, A. H. Strømman: Life cycle assessment of bioenergy systems: state of the art and future challenges. , Bioresour. Technol., Vol. 102, No. 2, pp. 437-51, 2011.

53) M. O'Hare, R. J. Plevin, J. I. Martin, A. D. Jones, A. Kendall, E. Hopson:Proper accounting for time increases crop-based biofuels' greenhouse gas deficit versus petroleum, Environ. Res. Lett., Vol. 4, No. 2, p. 24001, 2009.

(2016. 3. 22 受付)

\title{
A REVIEW OF SOCIAL DISCOUNT RATE FOR LIFE CYCLE ASSESSMENT OF WATER DISTRIBUTION SYSTEMS
}

\author{
Kohei HASEGAWA, Yasuhiro ARAI, and Akira KOIZUMI
}

Much of research to date has analyzed the effect of Social Discount Rate (SDR) on optimization of water distribution systems (WDSs). However, the relevant ministries in Japan have not reviewed the SDR both theoretically and practically over a long term even though SDR dramatically changes the results of analyses. To establish the methods of calibration of SDR and point out the issues that related research in optimization of WDSs must further investigate, this study reviewed a range of research analyzing the influence of SDR in WDSs from both theoretical and practical perspectives. In addition, this study conducted sensitivity analysis of SDR in a Japanese WDS. This study found that (1) current SDR set by Japanese ministries deviates from current interest rates and bond yield periods, (2) some previous studies have adapted inappropriate amortization for greenhouse gas emissions, (3) continuous use of relatively higher SDR causes inequality between cost and environmental burdens borne by later generations. Consequently, this study proposed that Japan's government should calibrate SDR to lower it and adopt declining discount rates after 40 years (i. e. Japan's maximum bond calculation year). 